\title{
PERSONAL BANKRUPTCIES FROM MACROECONOMIC PERSPECTIVE
}

\author{
Jan KUBÁLEK $K^{1}$ \\ University of Economics, Prague \\ Dagmar $\check{C} A M S K A^{2}$ \\ Czech Technical University in Prague \\ Jiř́ STROUHAL ${ }^{3}$ \\ Czech Technical University in Prague
}

\begin{abstract}
Personal bankruptcies are traditionally discussed from legal, microeconomic or social point of view. This paper focuses on the development of personal bankruptcies in the Czech Republic during the time period 2008-2016 and aims to connect performance of economy and the development of personal bankruptcies. As statistical tools there are used descriptive statistics and regression and correlation analysis. For the economy performance are used the measures of GDP, unemployment rate, household indebtedness and share of debts in default. Based on the results of the analysis there shall be said that lower economic performance influences increasing number of personal bankruptcies. This conclusion has significant consequences for the government and its politics, banks and other financial institutions.
\end{abstract}

\section{KEY WORDS}

debt relief; Czech Republic; macroeconomic development; over indebtedness

\section{JEL CLASSIFICATION}

G33, K35

\footnotetext{
${ }^{1}$ Correspondence address: Jan Kubálek, JUDr.; +420 385310 982; ak1@akkubalek.cz, University of Economics, Prague, nám. W. Churchilla 4, Prague 3, 130 67, Czech Republic, https://www.vse.cz/

${ }^{2}$ Correspondence address: Dagmar Čámská, Ing., Ph.D.; +420 224353 193; dagmar.camska@cvut.cz, Czech

Technical University in Prague, MIAS School of Business \& Interdisciplinary Studies, Department of Economic Studies, Kolejní 2637/2a, Prague 6, 160 00, Czech Republic, http://www.muvs.cvut.cz/

${ }^{3}$ Correspondence address: Jiří Strouhal, prof., Ing., Ph.D.; +420 224353 187; jiri.strouhal@cvut.cz, Czech Technical University in Prague, MIAS School of Business \& Interdisciplinary Studies, Department of Economic Studies, Kolejní 2637/2a, Prague 6, 160 00, Czech Republic, http://www.muvs.cvut.cz/
} 


\section{INTRODUCTION}

The term personal bankruptcy is not defined in current legal framework of the Czech Republic although it is highly used by general public as well as professionals. Personal bankruptcy is used as an alternative term for individuals' insolvency. Insolvency is a legal process under Act No. 182/2006 Coll. on Insolvency and its Resolution (generally called Insolvency Act) in the Czech Republic. The Insolvency Act, effective since January 2008, has offered in the Czech Republic for the first time the possibility of resolving the bankruptcy following not only liquidation as well as reorganization principle. Especially in the case of natural persons (non-entrepreneurs) it is a great revolution. Legal norms sometimes require revisions. The revisions should generally increase efficiency, shorten waiting time periods or strengthen the rights of one or other interested parties. This act has been already effective for more than nine years. It means some data are available for further decision making. On the other hand, many pieces of information are missing. The aim of this paper is to analyse the concept of personal bankruptcies from the macroeconomic point of view. The unfavourable macroeconomic conditions could be an impulse for the increasing number of personal bankruptcies. The reminder of this paper is as follows. Firstly, there would be provided a brief literature review on approached area, followed by the designing the model for the practical analysis. Conclusive remarks would be provided based on the results of the analysis.

\section{LITERATURE REVIEW}

Personal bankruptcy provides individuals a possibility to solve their complicated financial situation when they are not able to repay their debts anymore. Personal bankruptcy is mostly a question of legal framework (Draghici, 2015). Since 2008 the Insolvency Act has implemented debt relief as a manner of solving bankruptcy. The Czech legal norms were inspired by foreign legal frameworks, especially from Germany or USA (Frelichová, 2008). Clearing a non-entrepreneurial subject's debt is possible into two ways - monetization of debtor's assets and completing a payment plan. It is completed within five years and the debtors have to repay at least $30 \%$ of their unsecured debts. Experiences show that the repayment schedule dominates the monetization (Kislingerová et al., 2013).

The issue of personal bankruptcy is usually discussed from the microeconomic (Fišerová and Paseková, 2016, Ključnikov and Junger, 2013, Paulík et al., 2015 or Randáková and Bokšová, 2015), individual (Hospodka, et al., 2017 or Paseková, et al., 2015) or social perspectives (Paseková, 2013). Contrary, the macroeconomic situation is more connected with corporate insolvencies than debt reliefs. This statement can be proved by contributions by Kislingerová and Arltová (2013), Svobodová (2013), Kislingerová and Schönfeld (2014) or Louda (2016). Carter and Van Auken (2006) proved that the main reasons for insolvency of small enterprises are lack of knowledge, the impossibility of debt financing and the economic climate. On the other hand, personal bankruptcies are usually not connected with the general economic conditions. It must be emphasized that unexpected changes in personal life are supposed to be the primary trigger of nonentrepreneurs' insolvency (Kislingerová et al., 2013). Among these changes it may be mentioned illness, divorce, partner's death, loss of employment or only insufficient financial literacy whose connection with social standing was proved by Jappelli (2010). It can be added an approach of Smrčka and Arltová (2014) who studied the relation between debt and living standard.

Increasing household indebtedness (Hospodka et al., 2017, Kljucnikov, and Majková, 2016, or Smrčka, 2011) could lead to serious consequences and therefore the macroeconomic perspective of personal bankruptcies should not be overlooked. Especially current situation of loans and other credit products which are available as never before may be helpful for a worsening personal 
situation. These efforts are very rare in the literature. A small step can be visible in Fišerová and Paseková (2014) whose problem is an insufficiently long time series followed by the slow introduction of debt relief in the Czech Republic in the early stage and the macroeconomic situation affected by the consequences of the recent global crisis.

\section{METHODS}

Methods are related to the analysis of time series. The studied time series show the development of the number of personal bankruptcies and macroeconomic situation (GDP and unemployment) completed with the amount of bad debts in the economy. The data are described in the following part. The basic tools of descriptive statistics will be followed by regression and correlation analysis. The following paragraphs specify used time series and some necessary data transformation.

The analysis of this paper is based on the publicly available data although insolvency process is often criticised because of the lack of related information (Kislingerová, 2012). The individual insolvency cases are available in the insolvency register but it must be emphasized that it is not possible to aggregate these individual cases using information technologies (Smrčka, 2013). Therefore, the primary data source is total number of individuals' insolvency proposals published by Creditreform $(2015,2017)$. It is a time series from 2008 till 2016. It cannot be longer because of the enforcement of the Insolvency Act since 2008. The development of the number of the insolvency proposals will be compared with the macroeconomic conditions measured by gross domestic product (GDP) and unemployment. These indicators are regularly published by statistical offices as Czech Statistical Office or Eurostat. For both indicators annual data are used.

Aforementioned increasing household indebtedness can also have its impact. Therefore, the basic comparison between indebtedness and personal bankruptcies would be processed. Furthermore, total indebtedness cannot be used as an explanatory indicator because households draw loans more and more nowadays. Czech National Bank publishes also a value of bad household debts. The worsening macroeconomic conditions have consequences on the ability to repay debts. These data have to be transformed for our purposes due to absolute view. The increasing amount of loans has the consequence of the increasing amount of bad debts in the absolute values. However, the macroeconomic situation is stable and the general ability to repay debts does not change. Conversion of absolute indicators to relative one would solve this obstacle. Therefore, the share of bad debts is computed (bad debts/total household debts). Afterwards, the annual changes between the number of personal bankruptcies and the share of bad debts will be compared. The annual changes are expressed as chain indices (see equation 1).

$$
\begin{array}{r}
\text { Annual change } X=\frac{x_{n}}{x_{n-1}}-1 \\
\text { where } \mathrm{X}-\text { means analysed variable, } \\
\mathrm{n}-\text { means period (year). }
\end{array}
$$

\section{RESULTS}

The amount of personal bankruptcies steadily grew in the Czech Republic at the beginning of the analysed period. Concerned debtors could not solve their loans and other payables in a different way. As it can be seen from table 1 growth dynamics had been gradually slowing down and since 2014 there has been a year-on-year decline in the number of these insolvency proposals. Foreign experience shows that steady increases occurred in most countries since the introduction of the debt relief (Kislingerová et al., 2013, p. 43). The question remains whether, despite the steep growth of 
seven of the 9 monitored years, the unfavourable macroeconomic situation associated with the global crisis did not influence the results. The loss of employment was marked in the previous text as one of the changes in personal life causing personal bankruptcy. Poor economic performance and rising unemployment may result in more personal bankruptcies as compared to periods of low unemployment and high economic performance.

\section{Table 1 Development of debt relief proposals in the Czech Republic}

\begin{tabular}{|c|c|c|c|c|c|}
\hline YEAR & pROPOSALS & $\begin{array}{l}\text { aNNUAL } \\
\text { cHANGE }\end{array}$ & \multicolumn{3}{|c|}{$\begin{array}{l}\text { MAIN DESCRIPTIVE } \\
\text { STATISTICS }\end{array}$} \\
\hline 2008 & 1936 & & Mean & & 19671 \\
\hline 2009 & 4237 & $118.85 \%$ & \multicolumn{2}{|c|}{ Median } & 23830 \\
\hline 2010 & 10559 & $149.21 \%$ & \multicolumn{2}{|c|}{ Variation } & 10920 \\
\hline 2011 & 17600 & $66.68 \%$ & \multicolumn{2}{|c|}{ Minimum } & 1936 \\
\hline 2012 & 23830 & $35.40 \%$ & \multicolumn{2}{|c|}{ Maximum } & 31577 \\
\hline 2013 & 30888 & $29.62 \%$ & Percentiles & 25 & 7398 \\
\hline 2014 & 31577 & $2.23 \%$ & & 50 & 23830 \\
\hline 2015 & 29349 & $-7.06 \%$ & & 75 & 30118 \\
\hline 2016 & 27067 & $-7.78 \%$ & & & \\
\hline
\end{tabular}

(Source: authors based on Creditreform data, 2015, 2017)

Table 1 shows not only the development of debt relief proposals but also some basic descriptive statistics of this variable. It is visible that there are significant differences among analyzed years. The potential reasons for the high number of insolvency proposals could be global economic crisis leading to lower national output and related higher unemployment rate. There can be also other reasons connected more with social environment as lower personal literacy whose threat is connected with a large offer of loans and other credit products in the current market. It seems that credit products are available as never before. We will focus on the first mentioned reason further. The development of debt relief proposals and its time differences will be analyzed in relation to the macroeconomic situation expressed by annual GDP measured in mil. CZK and annual unemployment rate. Values of these two variables and their basic descriptive statistics are displayed by table 2 .

\begin{tabular}{|c|c|c|c|c|c|c|}
\hline Table 2 & \multicolumn{6}{|c|}{ Development of main macroeconomic indicators in the Czech Republ } \\
\hline \multirow[t]{2}{*}{ 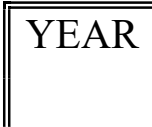 } & \multirow{2}{*}{$\begin{array}{l}\text { REAL GDP } \\
\text { (mil. CZK) }\end{array}$} & \multirow{2}{*}{$\begin{array}{c}\text { uNEMPLOYMENT } \\
\text { U }\end{array}$} & \multicolumn{4}{|c|}{ " main DESCRIPTIVE STATISTICS } \\
\hline & & & & & GDP & $\mathrm{U}$ \\
\hline 2008 & 3935698 & $4.40 \%$ & \multicolumn{2}{|l|}{ Mean } & 4136344 & $6.03 \%$ \\
\hline 2009 & 3820932 & $6.70 \%$ & \multicolumn{2}{|l|}{ Median } & 4032910 & $6.70 \%$ \\
\hline 2010 & 4011836 & $7.30 \%$ & \multicolumn{2}{|c|}{ Variation } & 261936 & $1.16 \%$ \\
\hline 2011 & 4032910 & $6.70 \%$ & \multicolumn{2}{|c|}{ Minimum } & 3820932 & $4.00 \%$ \\
\hline 2012 & 4001491 & $7.00 \%$ & \multicolumn{2}{|c|}{ Maximum } & 4665111 & $7.30 \%$ \\
\hline 2013 & 4040276 & $7.00 \%$ & Percentiles & 25 & 4001491 & $5.10 \%$ \\
\hline 2014 & 4209397 & $6.10 \%$ & & 50 & 4032910 & $6.70 \%$ \\
\hline 2015 & 4509446 & $5.10 \%$ & & 75 & 4209397 & $7.00 \%$ \\
\hline 2016 & 4665111 & $4.00 \%$ & & & & \\
\hline
\end{tabular}

(Source: authors based on CZSO data, 2017 and Eurostat data, 2017) 
Real gross domestic product has had the most stable development from the observed variables. There was significant decrease in 2009 and slight one in 2012 but all the other years were connected with steady increases. On one hand, unemployment rate followed the shifts of gross domestic product in 2009 and 2012 on the other hand unfavorable values remained also in 2010 and 2013. It means that decreases of the unemployment rate came later although there was already the increase of GDP.

The next step is conducting of regression analysis. Regression analysis is performed for the number of insolvency proposals as the dependent variable. As explanatory variables real GDP and unemployment rate are used. Results of the analysis are provided by table 3 and 4 . The result of regression whose explanatory variable is the unemployment rate is unconvincing (R-squared 0.000547). Without any doubts it is statistically insignificant at a 95 percent level because p-value is equal 0.95. Contrary, the regression with real GDP as explanatory variable provides more convincing results. It is displayed in table 3 . The model itself shows moderate dependence between real GDP and the number of debt relief proposals. The value of R-squared is equal to 0.4121 . It means that $41 \%$ of variability of dependent variable are explained by the proposed model. If we choose the significant level at a 95 percent both coefficients would be unfortunately insignificant. As a consequence, we decrease the significant level to a 90 percent level and this model can be used. Statistically it is moderate dependence according the value of R-squared. Unfortunately the model expresses that increasing real GDP leads to the higher amount of debt relief proposals how it is visible from the positive value of coefficient GDP.

\section{Table $3 \quad$ Regression analysis (GDP explanatory variable)}

\begin{tabular}{||c|c|c|c|c||}
\hline \hline Variable & Coefficient & Std. Error & t-Statistic & Prob. \\
\hline GDP & 0.026767 & 0.012081 & 2.215552 & 0.0623 \\
\hline C & -91044.23 & 50072.15 & -1.818261 & 0.1119 \\
\hline R-squared & 0.412193 & \multicolumn{2}{|c||}{ Mean dependent var } & 19671.44 \\
\hline Adjusted R-squared & 0.328221 & \multicolumn{2}{|c||}{ S.D. dependent var } & 11582.81 \\
\hline S.E. of regression & 9493.520 & \multicolumn{2}{|c||}{ Akaike info criterion } & 21.34774 \\
\hline Sum squared resid & $6.31 \mathrm{E}+08$ & \multicolumn{2}{|c|}{ Schwarz criterion } & 21.39156 \\
\hline Log likelihood & -94.06481 & Hannan-Quinn criter. & 21.25316 \\
\hline F-statistic & 4.908671 & Durbin-Watson stat & 0.507366 \\
\hline Prob(F-statistic) & 0.062285 & & \\
\hline
\end{tabular}

(Source: authors based on Creditreform data, 2015, 2017 and CZSO data, 2017)

\section{Table $4 \quad$ Regression analysis (Unemployment explanatory variable)}

\begin{tabular}{||c|c|c|c|c||}
\hline \hline Variable & Coefficient & Std. Error & t-Statistic & Prob. \\
\hline Unemployment & -220.8333 & 3567.614 & -0.061899 & 0.9524 \\
\hline C & 21003.81 & 21916.56 & 0.958353 & 0.3698 \\
\hline R-squared & 0.000547 & \multicolumn{2}{|c||}{ Mean dependent var } & 19671.44 \\
\hline Adjusted R-squared & -0.142232 & \multicolumn{2}{|c||}{ S.D. dependent var } & 11582.81 \\
\hline S.E. of regression & 12379.16 & Akaike info criterion & 21.87855 \\
\hline Sum squared resid & $1.07 \mathrm{E}+09$ & Schwarz criterion & 21.92237 \\
\hline Log likelihood & -96.45346 & Hannan-Quinn criter. & 21.78397 \\
\hline F-statistic & 0.003832 & Durbin-Watson stat & 0.185837 \\
\hline Prob(F-statistic) & 0.952373 & \multicolumn{3}{|l}{} \\
\hline
\end{tabular}

(Source: authors based on Creditreform data, 2015, 2017 and Eurostat data, 2017) 
Economically this dependence does not prove the basic idea that worsening economic performance leads to higher amount of debt relief proposals. The data have proved opposite relationship that the improving economic performance (growing GDP) leads to higher amount of debt relief proposals. This problematic conclusion is caused by the short time series and dynamic development of using debt relief in the case of individuals in the early phase. The development of the last two years shows that the number of the insolvency proposals has been decreasing when the country economic performance has improved.

As a consequence, another explanatory variable has to be searched which would connect general economic situation and personal bankruptcies. From the economic point of view there should exist a connection. Therefore, this analysis should go on searching a variable which would support statistically the economic point of view.

The increasing indebtedness has been already emphasized. The personal bankruptcy occurs only in the case if individuals are not able to repay their debts anymore. It means that there would be no institute of debt relief if there were no debts. Table 5 proves that households draw more and more credit. The total household indebtedness increased by $40 \%$ in the analysed time period. The absolute value of bad debts also increased from 2008 till 2013/4. Although the absolute value of bad debts has decreased since 2013 it still exceeds the values in first years. It must be emphasized that the first analysed years are the period of the recent global economic crisis.

First the economic sense of bad debts related to the debt relief proposals is discussed. The low performance of the economy has generally a negative impact on employment and wage policy of employers which is reflected in the more problematic ability of households to repay their credits. It is best visible in table 5, specifically indicator share of bad debts. Till 2010 there was a significant increase of bad debts share. In the time period 2010-2014 this share was above 4\%. Finally the proportion of debts in default significantly decreases in 2015 when it fell below 4\%. Such an observation is fully consistent with the findings about the amount of individuals' insolvency proposals. This research idea will be further statistically verified.

\section{Table $5 \quad$ Indebtedness of households in the Czech Republic in mil CZK}

\begin{tabular}{||c|c|c|c|c||}
\hline \hline \multirow{2}{*}{ YEAR } & & \multicolumn{3}{|c||}{ Default } \\
\cline { 3 - 5 } & Total debts & Bad debts & $\begin{array}{c}\text { Share of bad } \\
\text { debts }\end{array}$ & $\begin{array}{c}\text { Annual } \\
\text { change }\end{array}$ \\
\hline 2008 & 1155154 & 25592 & $2.22 \%$ & \\
\hline 2009 & 1210271 & 38702 & $3.20 \%$ & $44.34 \%$ \\
\hline 2010 & 1267869 & 53379 & $4.21 \%$ & $31.66 \%$ \\
\hline 2011 & 1330195 & 54368 & $4.09 \%$ & $-2.92 \%$ \\
\hline 2012 & 1372891 & 58750 & $4.28 \%$ & $4.70 \%$ \\
\hline 2013 & 1418876 & 59234 & $4.17 \%$ & $-2.44 \%$ \\
\hline 2014 & 1432104 & 58121 & $4.06 \%$ & $-2.79 \%$ \\
\hline 2015 & 1518693 & 53884 & $3.55 \%$ & $-12.58 \%$ \\
\hline 2016 & 1630017 & 45448 & $2.79 \%$ & $-21.42 \%$ \\
\hline
\end{tabular}

(Source: authors based on Czech National Bank data, 2017a, 2017b)

In the part dedicated to methods and data it has been already discussed that it has no sense to work with absolute data in this case. It is worthy to deal with relative values. Therefore, it will be compared the relative development of the number of debt relief proposals (table 1, third column) 
and the share of debts in default (table 5, last column). The development of both variables is displayed in figure 1 .

It seems the direction of development and the dynamics of both variables are consistent over the analysed time period. From the statistical tools the correlation analysis will be used. The regression itself is not wanted because it is difficult to define which variable is dependent and which is explanatory. The correlation coefficient is equal to 0.9. First it proves strong dependence between these two variables. Second the value is positive which means that increasing value of share of debts in default causes increasing number of the insolvency proposals of the individuals. It can be also postulated in the positive way. Decreasing value of share of bad debts in economy influences the number of debt reliefs whose amount is also decreasing. These two variables are significantly connected but it is impossible to determine dependency among each other. It can be postulated that they are the result of the same phenomenon.

\section{Figure 1 Annual change of debt relief proposals and share of bad debts}

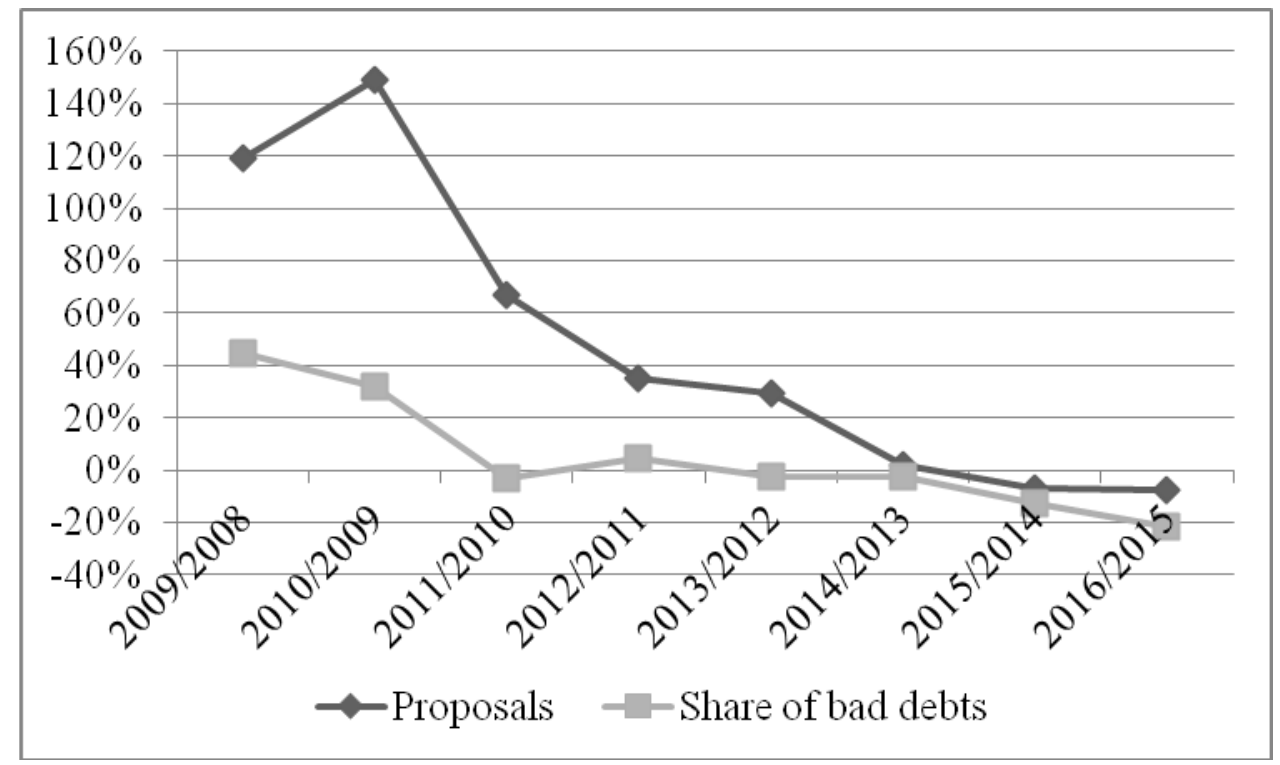

(Source: authors based on Creditreform data, 2015, 2017 and Czech National Bank data, 2017a, 2017b)

\section{DISCUSSION}

Implications of these research finding could be especially in the practice. It can be discussed the role of banks and other financial institutions. They have to deal with higher amount and proportion of debts in default during the phases of lower economic performance. It is not a new idea. However, personal bankruptcy solved as the debt relief is a new way. The creditors offer a possibility to start a new life after the 5 years' fulfilling recovery plan. The debtor is motivated to pay installments of the recovery plan. The probability for creditors to get at least some money back is higher than in the case of an individual enforcement. The individual enforcement is a never ending process therefore the debtors' motivation is lower and they often give it up. They escape in the net of social benefits or grey economy where their earnings are not taxed and confiscated by the enforcement administrator.

Other related parties are governmental institutions and insolvency administrators. Insolvency courts have to deal with higher amount of proposals during and after crisis periods. Therefore, they need 
more personal and material capacities during the specific time periods. It could seem that also the insolvency administrators have business very cyclical. It can be even postulated that their business is an example of anticyclical industry branch. Contrary, their work is not one-off. Peaks are observable during the time of the insolvency proposals. They have to find and monetize debtors' property and establish the recovery plan. Although it is not fully evident their work do not finish. They have to administrate recovery plan, transfer money to the creditors monthly and monitor debtors' activities and effort. The recovery plan will be fulfilled after five years. The economic cycle has 4-6 years on average and therefore the new peak of insolvency proposals will be coming.

\section{CONCLUSION}

This paper untraditionally focuses on the concept of personal bankruptcy in the direct link with the macroeconomic situation. Debt relief as a way to solve personal bankruptcy is usually dealt in the legal dimension of the insolvency law. Economic findings tend to be microeconomic, as debtors entering personal bankruptcy are individual economic players. Contrary, it can be found statements that social dimension prevails because personal bankruptcy enables individuals to start again without the debt burden. However, it is possible to aggregate the findings at the level of the whole economy and the microeconomic conception moves to macroeconomic one.

The paper's analysis dealt with the impact of the macroeconomic situation on the development and its dynamics of personal bankruptcies in the Czech Republic which occurred in the time period 2008-2016. The macroeconomic situation was described by gross domestic product and annual unemployment rate. The choice of these indicators is based on the economic connection between lower performance of the economy and worsening individual household situation which finishes in personal bankruptcy. Although economic justification seems reasonable it was not confirmed statistically. The unemployment rate was not a powerful explanatory variable at all. The relationship with gross domestic product showed a moderate dependence. Contrary, this dependence had been expected in opposite direction because of the economic sense. These obstacles are caused by the short time series and by dynamic early stages of debt relief in the Czech Republic. As a last step the level of household indebtedness and the number of individual insolvency proposals were examined. The direction of development and the dynamics of proposals and share of bad debts were consistent over the analysed time period.

The paper has not proved statistically the connection of personal bankruptcies with overall economic situation. This connection should be verified further when more data are available describing the length of at least three economic cycles (12-15 years). On the other hand, strong dependence between bad debts and personal bankruptcies was proved. It has serious implications, especially for government and financial institutions. They should reflect that increasing household indebtedness and worsening performance of economy lead to the increasing number of personal bankruptcies.

Some limitations of this research have been already mentioned. First the time series is not long enough because it does not contain enough economic cycles. Second the enforcement of the new insolvency law came in 2008 when the economic crisis was spreading through the world. As a consequence, it was observed radical upward trend of the personal insolvency proposals. This increase was probably more significant than in the time of economic expansion. On the other hand, personal bankruptcies are very specific and these cases are individual. There are not only macroeconomic factors, as well as microeconomic and non-economic. It is difficult to generalize them because there can be several reasons and consequences depend also on the related factors of personal situation and environment. 
Future research can be conducted in several directions. The research will be able to continue later when longer time series is available. It would be possible to omit the exceptional prior years when the insolvency law came into force. Another possibility is international comparison which can show that similar development can be observed in more countries as a consequence of the crisis period. There are two basic limitations. First is data availability and second is different national insolvency law. Econometric approach to modelling the amount personal bankruptcies should not be based only on the macroeconomic factors but also microeconomic and social variables could be added. Last but not least there is an issue of seasonality. A question may be asked if the personal insolvency proposals do not occur in some months more than in others. Further it can be searched reasons for this state of the world and consequences for the related parties as insolvency courts, insolvency administrators or specialized lawyers and consultants dealing with these cases.

\section{ACKNOWLEDGEMENT}

The paper is processed as one of the outputs of the research project "Insolvency of individuals in the Czech Republic - economic and non-economic social impacts" registered at Internal FPH Grant Agency of University of Economics, Prague under the registration No. IG309037.

\section{REFERENCES}

Carter, R., \& Van Auken, H. (2006) Small firm bankruptcy, Journal of Small Business Management, vol. 44, no.: 4, pp. 493-512.

Creditreform (2015). Vývoj insolvencí v České republice v roce 2014. Prague: Creditreform. Language version: CZ Available from http://www.creditreform.cz/fileadmin/user_upload/CR-

International/local_documents/cz/Presseartikel/Vyvoj_insolvenci_v_Ceske_republice_v_roce _2014.pdf. Consulted: 10.6.2017

Creditreform (2017). Vývoj insolvencí v České republice v roce 2016. Prague: Creditreform. Language version: CZ. Available from http://www.creditreform.cz/fileadmin/user_upload/CR-

International/local_documents/cz/Presseartikel/TZ_Insolvence_2016.pdf. Consulted: 10.6.2017

Czech National Bank (2017a). Residents - total households loans - in default. Prague: Czech National Bank. Language version: CZ, EN. Available from http://www.cnb.cz/cnb/STAT.ARADY_PKG.VYSTUP?p_period=12\&p_sort=2\&p_des=50\& p_sestuid $=29683 \& p \_u k a=1 \& p \_s t r i d=\overline{A F K} \& p \_o d=200803 \& p \_d o=201703 \& p \_l a n g=E N \& p \_f$ ormat $=0 \& p \_$decsep $=$. Consulted 12.6.2017

Czech National Bank (2017b). Payables, state, households. Prague: Czech National Bank. Language version: $\quad$ CZ, EN. Available from http://www.cnb.cz/cnb/STAT.ARADY_PKG.VYSTUP?p_period=3\&p_sort=2\&p_des=50\&p sestuid $=29683 \& p \_u k a=1 \% 2 \mathrm{C} 2 \% 2 \mathrm{C} 3 \% 2 \mathrm{C} 4 \% 2 \mathrm{C} 5 \% 2 \mathrm{C} 6 \% 2 \mathrm{C} 7 \% 2 \mathrm{C} 8 \% 2 \mathrm{C} 9 \% 2 \mathrm{C} 10 \% 2 \mathrm{C} 11 \%$ 2C12\&p_strid $=A F K \& p \_o d=200803 \& p \_d o=201612 \& p \_l a n g=C S \& p \_$format $=0 \& p \_d e c s e p=\%$ 2C. Consulted 12.6.2017 
CZSO (2017). GDP at Previous Year Average Prices. Prague: Czech Statistical Office. Language version: CZ. Available from https://www.czso.cz/documents/10180/46120893/hdpcr060217_r.xlsx. Consulted 11.6.2017

Draghici, C. (2015) Insolvency of Individuals in European Legislation - Great Britain. In International Conference of Law, European Studies and International Relations (pp. 173-178). Bucharest: Titu Maiorescu University.

Eurostat (2017). Unemployment rate - annual data. European Union: Eurostat. Language version: EN. Available from http://ec.europa.eu/eurostat/tgm/table.do?tab=table\&init=1\&plugin=1\&pcode=tipsun20\&lang uage $=$ en. Consulted 11.6.2017

Fišerová, Z. \& Paseková, M. (2014) The influence of the macroeconomic environment on insolvency of non-entrepreneurs in the Czech Republic. In DOKBAT 2014: 10th International Bata Conference. Sborník z vědecké conference. Zlín: Tomas Bata University in Zlin.

Fišerová, Z., \& Paseková, M. (2016) The microeconomic view on personal bankruptcy in the Czech Republic, International Advances in Economic Research, vol. 22, no.: 4, pp. 477-478.

Frelichová, K. (2008) Oddlužení neboli osobní bankrot. Aplikované právo, vol. 2, 23p.

Hospodka, J., Buben, O., Randáková, M., \& Bokšová, J. (2017) Personal Bankruptcy in the Czech Republic: Age and Gender of the Debtors and Structure of the Creditors, European Financial and Accounting Journal, vol. 12, no.: 1, pp. 5-18.

Jappelli, T. (2010) Financial Literacy: An International Comparison, Economic Journal, vol. 120, no.: 548 , pp. $429-451$.

Kislingerová, E. (2012) Lack of Insolvency - Related Information as a Factor Limiting the Reform of the Insolvency System. In D. Pavelková, J. Strouhal \& M. Paseková (Eds.), Advances in Finance \& Accounting (pp. 180-185). Athens: WSEAS Press.

Kislingerová, E., \& Arltová, M. (2013) Forecasting the Number of Insolvency Petitions and Bankruptcies for 2013-2014. In E. Jirčíková, A. Knápková \& E. Pastuszková (Eds.), Proceedings of the 6th International Scientific Conference: Finance and the performance of Firms in Science, Education and Practice (pp. 336-347). Zlín: Thomas Bata University.

Kislingerová, E., Richter, T., \& Smrčka, L. et al. (2013) Insolvenční praxe v České republice v období 2008-2013. 1st edition. Praha: C. H. Beck. ISBN 978-80-7400-497-1.

Kislingerová, E., \& Schönfeld, J. (2014) The development of insolvency in the entrepreneurial sphere in the Czech Republic during the crisis years. In M. Čulík (Ed.), Managing and Modelling of Financial Risks 7th International Scientific Conference Proceedings (Part II) (pp. 367-378). Ostrava: VŠB - Technická univerzita Ostrava.

Ključnikov, A., Junger, R. (2013). Barriers for foreign direct investments in Belarus: Case of business logistics. In Proceedings of the Carpathian Logistics Congress.

Kljucnikov, A., Sobeková-Majková, M. (2016). Impact of Gender in the Perception of Administrative Burdens among Young Entrepreneurs-Evidence from Slovakia. Journal of Competitiveness, 8(2). 
Louda, L. (2016) Trends in the Number of Insolvency Proposals. In P. Jedlička (Ed.), Double-blind peer reviewed proceedings of the international scientific conference Hradec Economic Days 2016 (pp. 532-540). Hradec Králové: University of Hradec Králové.

Paulík, J., Kombo, F., \& Ključnikov, A. (2015). CSR as a driver of satisfaction and loyalty in commercial banks in the Czech Republic. Journal of International Studies.

Paseková, M. (2013) Personal Bankruptcy and its Social Implications, International Advances in Economic Research, vol. 19, no. 3, pp. 319-320.

Paseková, M. Fišerová, Z., Smrčka, L., \& Bařinová, D. (2015). Debt relief of individuals and the rate of satisfaction of their creditors in the Czech Republic. In E. Pastuszková, Z. Crhová, J. Vychytilová, B. Vytrhlíková \& A. Knápková (Eds.), Proceedings of the 7th International Scientific Conference Finance and the Performance of Firms in Science, Education, and Practice (1169-1187). Zlín: Thomas Bata University.

Randáková, M., \& Bokšová, J. (2015) Bankruptcy of individuals in the Czech Republic. In Proceedings ICABR (pp. 460-469). Brno: Mendel University in Brno.

Smrčka, L (2011). Government Indebtedness and Family Indebtedness as an Inseparable Twins in the Modern World, International Journal of Mathematical Models and Methods in Applied Sciences, vol. 5, no.: 3, pp. 480-489.

Smrčka, L. (2013) The problems of the insolvency register in the Czech Republic from the perspective of information technology. In A. Rocha, A. M. Correia, T. Wilson \& K. A. Stroetmann (Eds.), Advances in Information Systems and Technologies (10 p.). Heidelberg: Springer.

Smrčka, L., \& Arltová, M. (2014) Debt in Relation to the Standard of Living Enjoyed by the Population of Developed Countries, Prague economic papers, vol. 23, no.: 1, pp. 84-107.

Svodobová, L. Vývoj insolvenčního řízení v České republice, Ekonomika a management, vol. 2013, no.: $1,11 \mathrm{p}$. 